Research Article

\title{
Assessment of climate change impact on double-cropping systems
}

\author{
Maria Carolina da Silva Andrea ${ }^{1}\left[\right.$ [ $\cdot$ Rivanildo Dallacort $^{1} \cdot$ Rafael Cesar Tieppo $^{1} \cdot$ João Danilo Barbieri ${ }^{2}$
}

Received: 19 November 2019 / Accepted: 25 February 2020 / Published online: 3 March 2020

(c) Springer Nature Switzerland AG 2020

\begin{abstract}
This study assessed potential impacts of climate on the dynamics of soybean-maize systems, a widespread cropping practice in Central Brazil, in regions of Mato Grosso state. Baseline (historical) and future climate scenarios in the mid and end of the twenty-first century were locally defined. Climate projections were input in a crop model, which was used to analyze their impact on first season's crop (soybean), and more emphasis was given on the second season's crop, maize development. In the climate projections, we observed a generalized increase in temperature for all scenarios, with variability of rainfall amount and pattern. Soybean growth showed a general enlargement of cycle length (average of up to $16 \%$ ) and increase of yields (average of up to $34 \%$ ) in future conditions. Soybean sowing dates and future climate contributed to the shortening of recommended maize sowing window and yield decreases. At most extreme scenarios of future climate, only soybean sown at the earliest dates would enable the latest maize sowing dates, bringing the greatest losses to the latter crop. Estimated maize yields showed relative average variations from baseline of $-22.5 \%$ and $-32.5 \%$ in RCP 4.5 in the mid and end of the century, while variations were of $-34 \%$ and $-55 \%$ in RCP 8.5 in the mid and end of the century, respectively. Timing of soybean sowing dates in a future climate will become more important in influencing the dynamics of subsequent maize's sowing dates and yields under a more extreme and unfavorable climate for its development.
\end{abstract}

Keywords Climate change $\cdot$ Climate impacts $\cdot$ GCMs $\cdot$ Brazil $\cdot$ Staple crops · Mato Grosso

\section{Introduction}

Impacts of climate change on agriculture have been a widely addressed issue $[19,39]$ due to the significant role that climate plays in the variability of agricultural yield levels [36]. A large share of worldwide studies on climate change impacts in agriculture is devoted to staple crops such as maize, soybean, wheat and rice $[7,29,46]$, since variability on their production can potentially affect most of the world population.

At world level, the effects of climate change on staple crops are expected to be overall negative $[14,46]$, although regionally this can vary substantially with the crop and climate type $[12,19,32,43]$. Regions with temperate climate can experience some yield increase depending on the crop [12], but warmer climate regions are more at risk of experiencing decreases in yields, due to the overall increase in (already warm) average temperatures, which may overcome the variable effect of $\mathrm{CO}_{2}$ fertilization [29] and the changes in rainfall patterns.

Crop modeling represents the major share of climate change impact studies in agriculture $[12,20]$ due to time and money constraints that experimental studies of plant physiology responses to a changing environment impose

Electronic supplementary material The online version of this article (https://doi.org/10.1007/s42452-020-2325-z) contains supplementary material, which is available to authorized users.

$\triangle$ Maria Carolina da Silva Andrea, maria.andrea@alumni.usp.br| ${ }^{1}$ Universidade do Estado de Mato Grosso, Campus Universitário Professor Eugênio Carlos Stieler de Tangará da Serra, Tangará da Serra, MT 78300-000, Brazil. ²Universidade Estadual de Maringá, Maringá, PR, Brazil. 
$[2,29]$. These crop modeling studies can be somewhat complex in the sense that climate simulation data (from general circulation models, GCMs) are usually also used. The use of these GCMs is intrinsically related to possible future outcomes of society, resulting in radiative forcing (Earth's energy balance) scenarios through the representative concentration pathways (RCPs) [24].

Studies about climate change impacts on agriculture in Brazil have been experiencing a recent development [1, $11,20]$, although studies that include Mato Grosso state, a major national agricultural producer, are still scarce or do not explore many of the state regions [26, 30, 32]. The state, one of the largest soybean and maize producers in the country [16] (which is also one of the main worldwide productions of these grains), is home of the biomes Pantanal, Cerrado and Amazônia, known for their susceptibility to climate change effects $[10,27]$.

The double-cropping system is a common practice in most of Central Brazil, in which two crops, commonly soybean prior to maize, are cultivated in the same area during the agricultural year. This system became possible through the evolution of adapted soybean materials to Central Brazil [1] as well as a rainy season that may provide a share of crop's water requirements. It starts with soybean at the beginning of the agricultural season (September-October), which is also the beginning of the rains. Maize, also called as "off-season," has its sowing directly dependent on soybean harvest and mandatorily experiences the decrease and end of the rainy season (starting in March) during its development, also being subject to a more intense interannual yield variability due to water stress $[5,18]$.

Studies have been addressing the impacts of climate change effects on this double cropping dynamics in Brazilian regions. It has been estimated that in the future soybean yields may increase, but only if this single crop is chosen to be cultivated; when opting for the double cropping, soybean would have to be sown earlier, which could decrease its yields by up to $25 \%$ (if sown at the beginning of typical sowing window) in order to allow the cultivation of maize [32].

Assessing the impact of climate change on agricultural output solely by yields may not be sufficient. Future estimations also show a reduction of suitable areas for double cropping in Central Brazil and Mato Grosso of 17\% due to changes in rainfall patterns [1]. The assessment of area added to cropping frequency is able to capture approximately $70 \%$ of changes in agricultural output due to climate [15]. Double-cropping soybean-maize systems may benefit from these analyzes by addressing aspects of the system that go beyond yields exclusively.

The objective of this study was to analyze potential impacts of projected climate on the dynamics of soybean and maize, grown in double-cropping systems in regions of Mato Grosso. We aim to provide a sense of how climate change can potentially affect a current agricultural production practice beyond their yields, specifically concerning the off-season's crop. This main objective was accomplished through the following: (i) adjustment of a crop model by means of experimental information; (ii) assessment of baseline and future climate conditions by means of two RCPs and two periods of the century; (iii) estimation of soybean and maize development across baseline and future scenarios; and (iv) assessment of effects from future climate on crops.

\section{Materials and methods}

\subsection{Assessed regions, crop model, experimental data and model adjustment}

This study covered ten regions in Mato Grosso state, located in Midwestern Brazil, represented by the municipalities of Cáceres (MTTA), Cuiabá (MTCU), Canarana (MTCN), Diamantino (MTDI), Nova Xavantina (MTNX), Poxoréo (MTPO), Sinop (MTSI), São José do Rio Claro (MTSJ) e Tangará da Serra (MTTA) (Fig. 1). Representative climate, soil and crop management information for each region was used for their characterization (see details in Online Resource 1).

Sections 2.1 and 2.2 describe data used in the model to perform the simulations. Main steps in this process include model adjustment by means of experimental data (Sect. 2.1), local environmental data of climate and soil (Sect. 2.2 and Online Resource 1) and crop management (Sect. 2.2).

The Decision Support System for Agrotechnology Transfer (DSSAT) version 4.7.0.0 [21, 25] was used for soybean (CROPGRO soybean) and maize (CSM CERES Maize) simulations. The software has been long used in Brazilian conditions, presenting satisfactory results [42] also at climate change conditions [31]. The model was adjusted and evaluated by using experimental data from a specific region of Mato Grosso state (MTTA) for two cropping seasons: 2015/2016 and 2017/2018 (see details of experiments in $[8,38]$, respectively). Both crops were cultivated in both irrigated and rainfed conditions, with optimal management practices. Soybean and maize materials used in experimental conditions were, respectively, an 8.2 maturity group cultivar and an early maturity hybrid. Model adjustment process was started by using DSSAT's soybean default cultivar of group 8 maturity and a maize default short season maturity hybrid. Model adjustment was performed by automating the estimation 


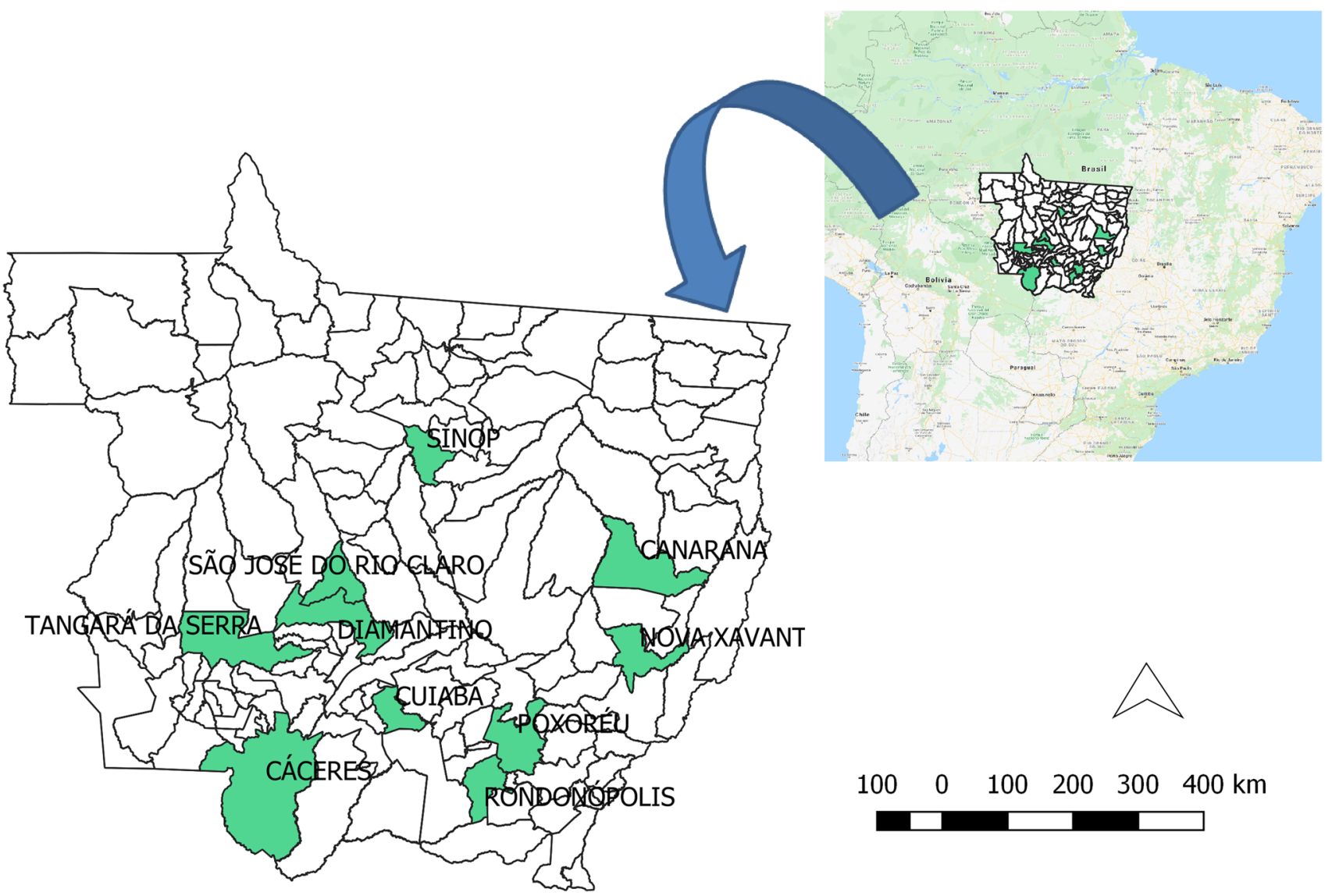

Fig. 1 Localization of the assessed regions in Mato Grosso, Brazil. Regions in the figure refer to the municipalities of Cáceres, Canarana, Cuiabá, Diamantino, Nova Xavantina, Poxoréo, Ron- donópolis, São José do Rio Claro, Sinop and Tangará da Serra. Maps developed by using QGIS software [34].

\subsection{Baseline and future scenarios of climate and yields}

\subsubsection{Climate}

In this study, "baseline" refers to the period of 1980-2010 $[41,42]$ of each region. It was represented by observed daily maximum and minimum temperatures, solar radiation and wind, obtained from the National Institute of Meteorology [23] and daily rainfall data, which were obtained from the National Agency of Waters [4]. Observed daily climate data can be a bottleneck in the country; thus, due to the fact that some regions did not present the full thirty-year series, a gridded database $\left(0.25^{\circ} \times 0.25^{\circ}\right.$ highresolution grids) developed for Brazil and consisting of be observed in Online Resource 2. 
daily climate variables [45], was used for the purpose of completing the baseline (1980-2010) series. Details of baseline climate can be observed in Online Resource 3.

The construction of future climate projections started with the use of the Agricultural Model Intercomparison and Improvement Project (AgMIP) methodology of Climate Scenario Generator [39], in which 29 GCMs were available. According to this methodology, GCMs are used along with the multiple scenario changes of choice (RCP, period of the century) and applied to baseline data in order to provide datasets of local climate projections. Since the proposed methodology resulted in a large amount of data, we also used an approach to subset representative GCMs projections based on the profile of each region's climate [40], also developed within the AgMIP project. The approach, named Representative Temperature and Precipitation (T\&P) GCM Subsetting Approach, uses a statistical approach to subset 5 of the projections from GCMs that represent the profile of the full ensemble of temperature and rain changes (relatively cool/dry, $\mathrm{cool} / \mathrm{wet}$, hot/dry, hot/wet and middle), thus resulting in a reduced amount of data. The latter approach was applied in each region and agricultural season, meaning that each region provided two sets of representative GCMs: for first and second agricultural seasons. The subset models were then used to perform the crop simulations. Detailed identification of all the $29 \mathrm{GCMs}$ used in the subsetting approach, as well as details of the methodology, can be found in [40]; summarization of GCMs can be observed in Online Resource 4. By using this approach, the study provided estimates representing a broad range of occurrences of future climate. Future periods were defined as: mid of the century (2040-2070) and end of the century (2070-2100). For each climate scenario, an average $\left[\mathrm{CO}_{2}\right]$ was used to run the crop simulations as follows: $360 ; 495$; 532; 572; and 803 ppm for baseline; RCP 4.5 for mid; RCP 4.5 for end; RCP 8.5 for mid; and RCP for 8.5 end of the century, respectively.

\subsubsection{Crop's management}

In the baseline period, we used three soybean's experiments sowing dates that were within the cultivar's recommended sowing window (October-November) [13] and considered them as early (October 6), medium (October 21 ) and late (November 5) sowing dates. By using simulated soybeans' cycle length at these sowing dates, the "possible" sowing dates for maize were later defined, also according to the latter crop's recommended sowing window. By doing this, results from this study were intended to raise awareness on possible outcomes of a changing climate in the Brazilian double cropping of soybean-maize systems, giving more emphasis on maize due to its more risky period of growth and development during the year due to the more intense water deficit. Maize sowing windows were then defined according to a 10-day interval, using as guide a recommended sowing window for an early maturity hybrid [13] available for all assessed regions. The adjusted model (see Sect. 2.1), baseline climate data and sowing dates were used to run the simulations for the baseline period in conditions wherein the only limitation was water. These results were then considered as the reference point for further analysis of future conditions.

Crop simulations for future climate projections were run for the following time periods and RCPs: 2040-2070 (mid of the century); 2070-2100 (end of the century); RCP 4.5 and RCP 8.5 forcing scenarios. In terms of sowing dates, the same approach used in baseline scenario was used for the scenarios of climate projections, in which maize's sowing date was dependent on soybean's harvest. It was then possible to assess the impact of future climate on the dynamics of double-cropping systems and in their yields.

\subsection{Assessment of climate-yield relationship on double-cropping systems}

The assessment of average future climate projections was performed using baseline climate as a reference condition for each region. Temperature and rainfall changes were assessed in absolute $\left({ }^{\circ} \mathrm{C}\right)$ and relative $(\%)$ terms, respectively, compared to baseline. Emphasis was given on these variables since these are the main climatic constraints in regional agriculture.

Analysis comprising of soybean's performance (sowing date vs. duration of cycle and yields) and its impact on maize's development in future scenarios was the main core of the assessment. While for soybean three representative sowing dates were used and kept constant in baseline and in future climate (see soybean results in Online Resource 5), for maize the sowing dates were dependent on soybean's cycle.

Data organization, analysis and visualization as detailed in Sect. 2 of this study were performed using R software: $R$ 3.5.2 [35] and the tidyverse (v1.2.1) package [44].

\section{Results}

\subsection{Climate assessment}

\subsubsection{Baseline climate}

Baseline climate of all assessed regions can be observed in more detail in Online Resource 3. In this section, we provided a brief discussion on regional climate conditions and 
emphasized the comparison of climate projections over baseline conditions.

All assessed regions share the same general aspect of monthly average temperatures and rainfall over the year, although slightly varying in absolute levels and their variability, typical characteristics found in Brazilian Cerrado biome. During autumn and winter, it is possible to observe relative decreases in average temperatures (but an overall warm climate), as also accentuated decreases in rainfall, characterizing the Aw type of tropical climate with dry winter, in one of its many occurrences across Brazilian territory [3]. Around September, it is possible to observe relative increases in average temperatures, and rainfall starts to increase around October, characterizing the rainfall season until March (spring and summer).

\subsubsection{Future climate}

Analysis regarding climate projections and crop simulations was performed by using only the subset of GCMs for each scenario, thus significantly reducing the amount of input data (see Online Resource 3 for details of the subset of GCMs). In Figs. 2 and 3, it is possible to observe the monthly average changes of average temperature and accumulated rainfall, by using the representative GCMs for each of the assessed scenarios: emissions (RCPs), time period (mid and end of the century) and regions. These values can also be found in Online Resource 4.

In terms of temperatures, together with the already widely known result of a general warmer condition in the coming decades [24], absolute $\left({ }^{\circ} \mathrm{C}\right)$ temperature increases were even more accentuated in the end of the year, which corresponds to late spring-summer. In RCP 4.5 temperatures have increased by an average of 2.2 and $2.7^{\circ} \mathrm{C}$ ( $\mathrm{mid}$ and end of the century), while on RCP 8.5 these values were of 2.9 and $4.8{ }^{\circ} \mathrm{C}$ (mid and end of the century) across all regions.

Regarding rainfall, in relative (\%) terms, drier months (April-May to August-September) presented an overall neutral-to-negative tendency (no changes to decreases of rain), while rainy season months presented positive changes (increases). Relative changes in RCP 4.5 were
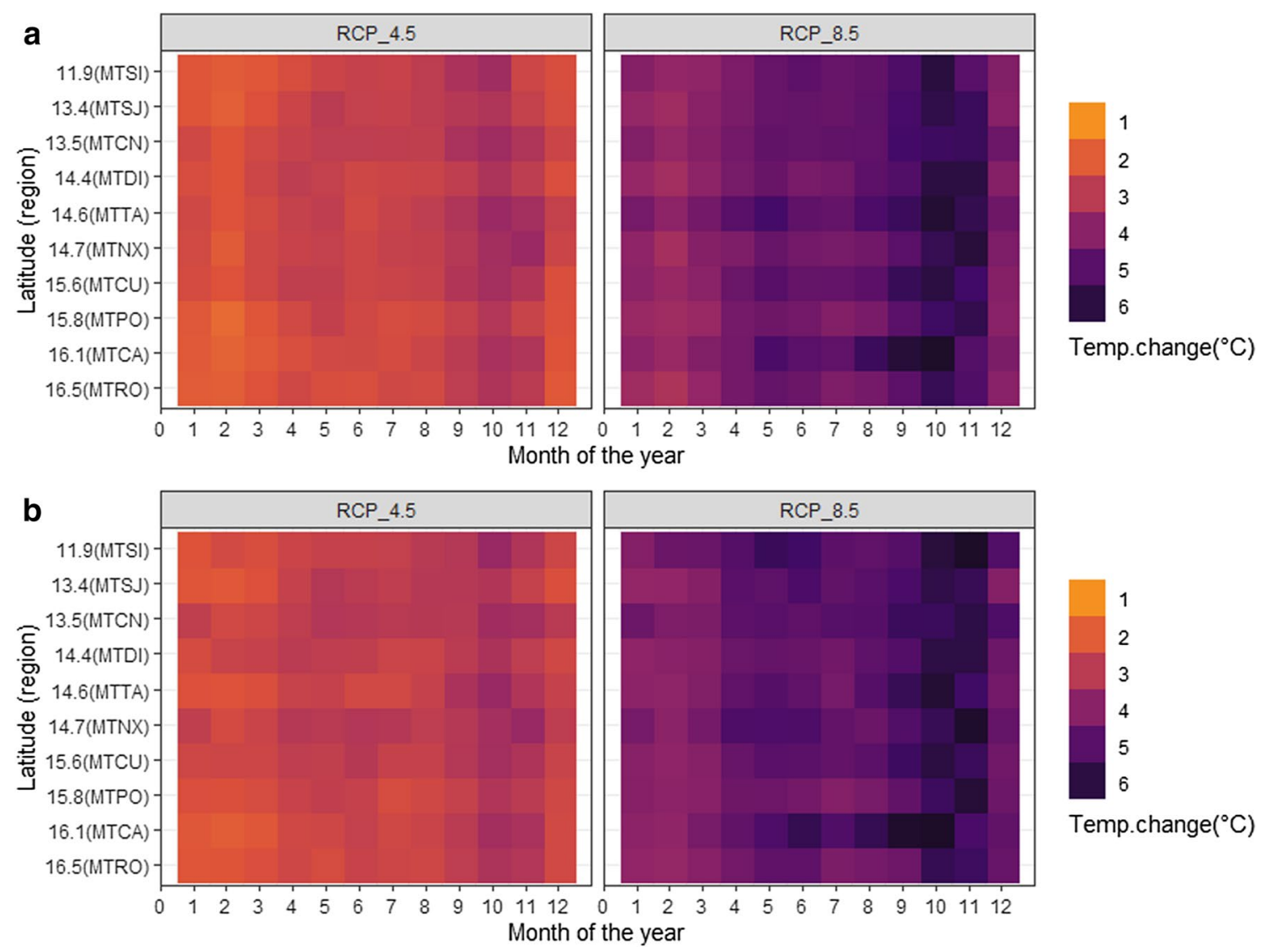

Fig. 2 Monthly changes in average temperature (in ${ }^{\circ} \mathrm{C}$ ) for the projected scenarios of a mid of the century, 2040-2070, and $\mathbf{b}$ end of the century, 2070-2100, at RCP 4.5 and RCP 8.5 emission scenarios for regions in Mato Grosso state using the baseline climate,
1980-2010, as reference. Changes were determined by using an average of the representative GCMs for each region, emission and time period scenario. Description of the subset of GCMs for each scenario can be found in Online Resource 4 

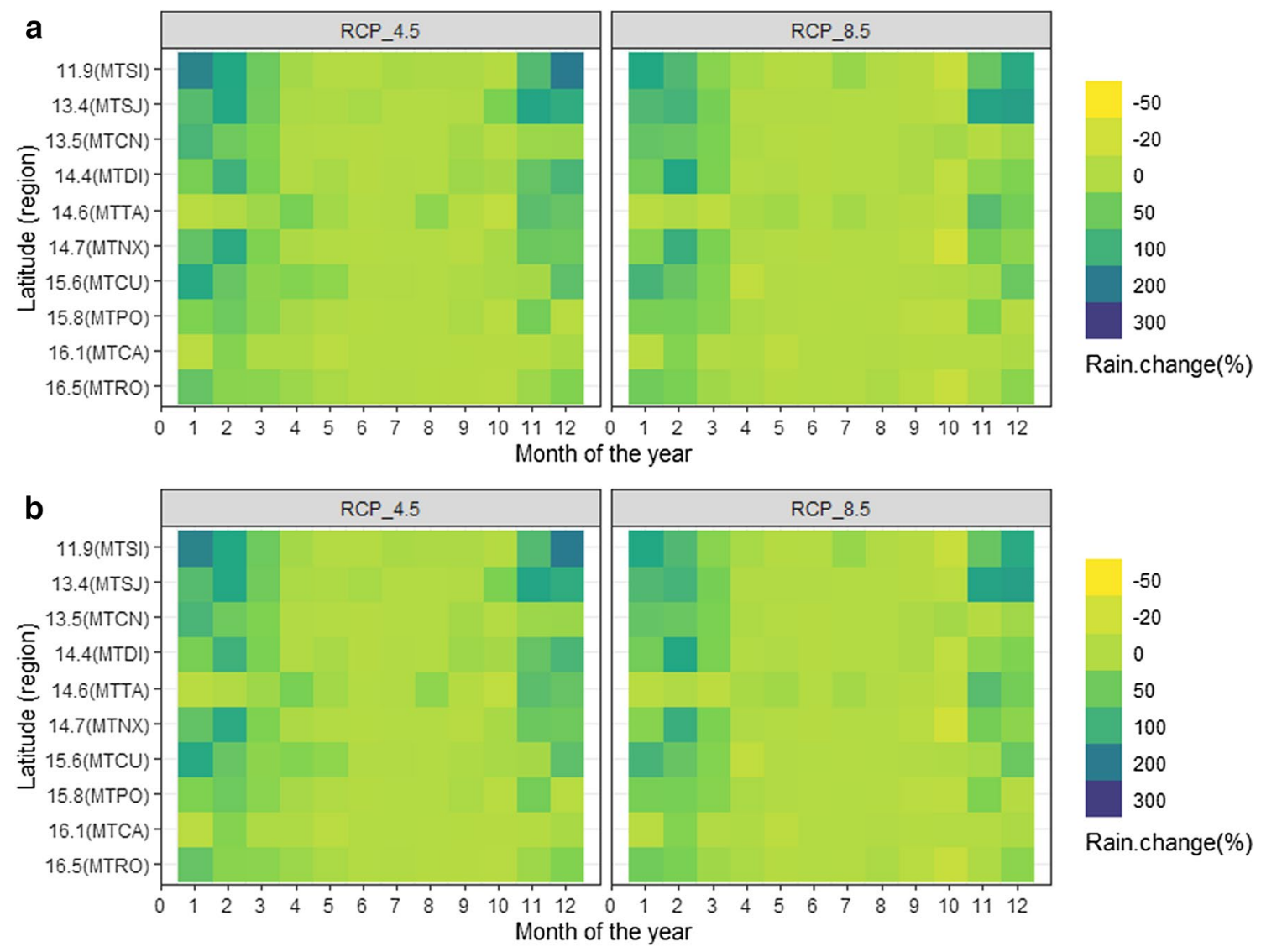

Rain.change(\%)

Fig. 3 Monthly changes in average cumulative rainfall (in \%) for the projected scenarios of a mid of the century, 2040-2070, and $\mathbf{b}$ end of the century, 2070-2100, at RCP 4.5 and RCP 8.5 emission scenarios for regions in Mato Grosso state using the baseline climate,

higher, 43 and $41 \%$ (mid and end of the century), while in RCP 8.5 changes were of 35 and $28 \%$, respectively. Details of regional average changes can be observed in Online Resource 4.

\subsection{Impacts on maize as a off-season crop}

\subsubsection{Soybean harvest date and maize sowing windows}

In Table 1, it is possible to observe the average length of each soybean scenario (see Online Resource 5 for more details of soybean results), which was also used to define the possible beginning of maize cycle. The possible start of maize cycle was determined considering the limits of the recommended sowing window for an early maturity hybrid.

Maize sowing dates for each scenario were determined considering the crop's recommended sowing window interval (January 1-February 20) by a 10-day interval and labeled as follows: M1 = January $1 ; M 2=$ January
1980-2010, as reference. Changes were determined by using an average of the representative GCMs for each region, emission and time period scenario. Description of the subset of GCMs for each scenario can be found in Online Resource 4

$11 ; M 3=$ January $21 ; M 4=$ February $1 ; M 5=$ February 11 , along with previous results from simulated soybean cycles. By using this approach, sowing dates of projected climate scenarios would have to fall within this interval to be considered viable.

The possible starting dates for maize cycle, as shown in Table 1, indicate a general tendency of delaying maize starts as the later soybean is sown. This tendency reaches more accentuated delays in the end of the century at RCP 8.5 scenario. Even in baseline conditions, if soybean is not sown at early dates (i.e., right after the regulated period of phytosanitary safety in the state, "sanitary break," starting September 15), maize's start at its earlier dates of January gets compromised. Following this approach, almost all projected scenarios could perform maize sowing at M3-M5, except for the most severe scenario of emissions in the end of the century, RCP 8.5, wherein only sowing dates M4 and M5 would be possible. 
Table 1 Soybean-maize succession dynamics in baseline and projected climate scenarios according to sowing dates in Mato Grosso state

\begin{tabular}{|c|c|c|c|c|c|c|c|c|c|c|}
\hline Scen & rios & Soybea & D. & & & & th of the & year & & \\
\hline & Period & & & & January & & & February & & March \\
\hline & century & & & 1 & 2 & 3 & 1 & 2 & 3 & 1 \\
\hline & & & $\begin{array}{c}\text { Maize } \\
\text { recommended } \\
\text { S.D. }\end{array}$ & M1 & M2 & M3 & M4 & M5 & & \\
\hline & & S1 & Soy: 107 days & & $\mathrm{Mz}$ & & & & & \\
\hline Baseline & - & S2 & Soy: 105 days & & & & $\mathrm{Mz}$ & & & \\
\hline & & S3 & Soy: 105 days & & & & & $\mathrm{Mz}$ & & \\
\hline & & S1 & Soy: 111 days & & & $\mathrm{Mz}$ & & & & \\
\hline & Mid & $\mathrm{S} 2$ & Soy: 109 days & & & & $\mathrm{Mz}$ & & & \\
\hline & & S3 & Soy: 107 days & & & & & $\mathrm{Mz}$ & & \\
\hline & & S1 & Soy: 113 days & & & $\mathrm{Mz}$ & & & & \\
\hline & End & $\mathrm{S} 2$ & Soy: 111 days & & & & $\mathrm{Mz}$ & & & \\
\hline & & S3 & Soy: 108 days & & & & & $\mathrm{Mz}$ & & \\
\hline & & S1 & Soy: 113 days & & & $\mathrm{Mz}$ & & & & \\
\hline & Mid & $\mathrm{S} 2$ & Soy: 111 days & & & & $\mathrm{Mz}$ & & & \\
\hline & & S3 & Soy: 108 days & & & & & $\mathrm{Mz}$ & & \\
\hline & & S1 & Soy: 127 days & & & & $\mathrm{Mz}$ & & & \\
\hline & End & S2 & Soy: 125 days & & & & & & $\mathrm{x}$ & \\
\hline & & S3 & Soy: 118 days & & & & & & & $\mathrm{x}$ \\
\hline
\end{tabular}

Obs: S.D. = sowing date. $\mathrm{Mz}=$ maize, referring to its start. Each month was divided into a 10 -day period $(1=1$ st to 10 th; $2=11$ th to 20 th; $3=21$ st to the last day of the month) to determine maize's sowing windows. S1, S2 and S3 indicate soybean's sowing date (columnwise). M1-M5 indicate maize recommended sowing date (rowwise) [13] here considered as the first day of each 10-day period and takes into consideration an early maturity hybrid and medium texture to clayey soils all regions. Dark blue indicates soybean up to harvest, and light blue indicates the possible start of maize cycle. Red-colored " $x$ " indicates possible start of maize cycle, but that falls outside the current recommended range. Soybean cycle length values are an average for all regions. See more details of soybean's development in each region and scenario in Online Resource 5

\subsubsection{Maize yields over time and under different sowing dates}

Maize sowing dates, as presented in Table 1, were used to perform yield simulations (Figs. 4, 5). Presented results give emphasis on the impact of possible recommended sowing dates under on the evolution of maize yields over time. The earliest recommended maize sowing dates (M1, M2) were not used in future climate simulations since none of soybean's simulated scenarios allowed the start of maize's cycle to take place in early January. Baseline yields were not fully represented in Figs. 3 and 4, only an average over the period, since the main focus was to indicate the effect of advancing time in yields. The overall range of average simulated yield values for baseline (5.7-6.0 $\mathrm{t} \mathrm{ha}^{-1}$ across regions) is coherent with recent reported values for the state's regions [22].
The scatter plots presented in Figs. 4 and 5 show that absolute yield values under future climate in different sowing dates are mostly below the baseline average yields. The dispersion of points over the year is mainly determined by climate variability, which may be more or less intense depending on the region. Linear regression equations were fitted for each sowing date of each assessed scenario, and an ANOVA was performed to assess the effect of time on maize yields. Despite the variability of estimated yields over the years, it is possible to observe that in most of the evaluated scenarios, there is statistical evidence of the occurrence of decreases in productivity levels over time up to the end of the century, at the level of 0.05. At RCP 8.5 scenarios, not all sowing dates were possible according to currently recommended sowing window, such as $\mathrm{M} 3$ in the end of the century (Table 1). In these cases, the effect was also not always significant. 

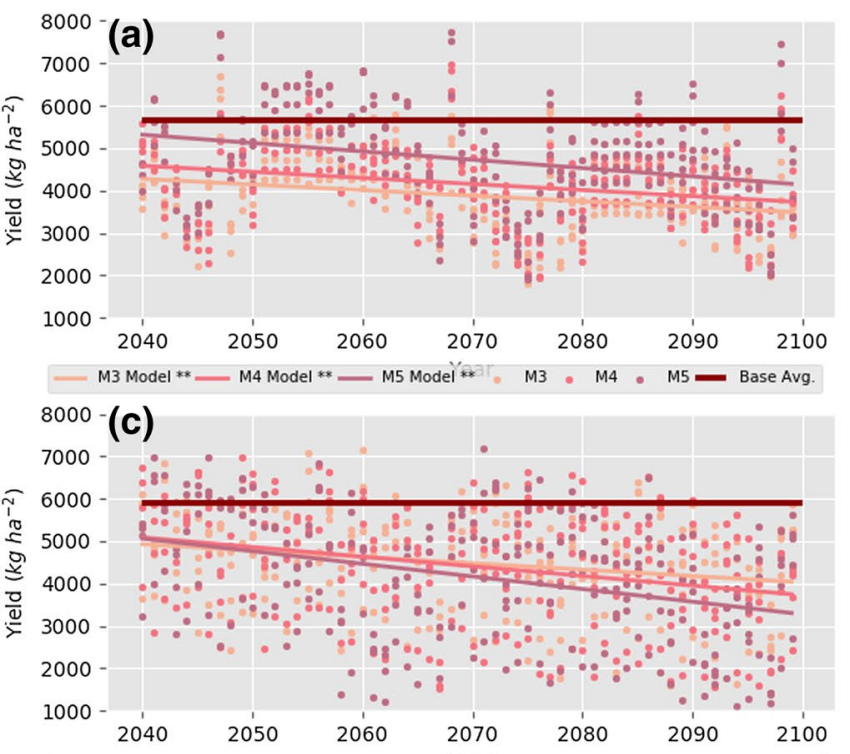

- M3 Model ** _ M4 Model ** M5 Model **I! M3 。 M4 。 M5 — Base Avg.

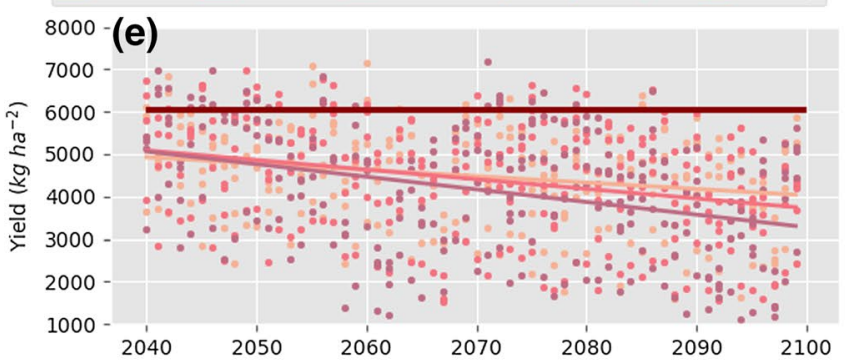

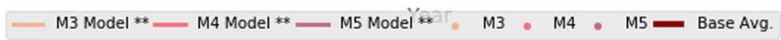

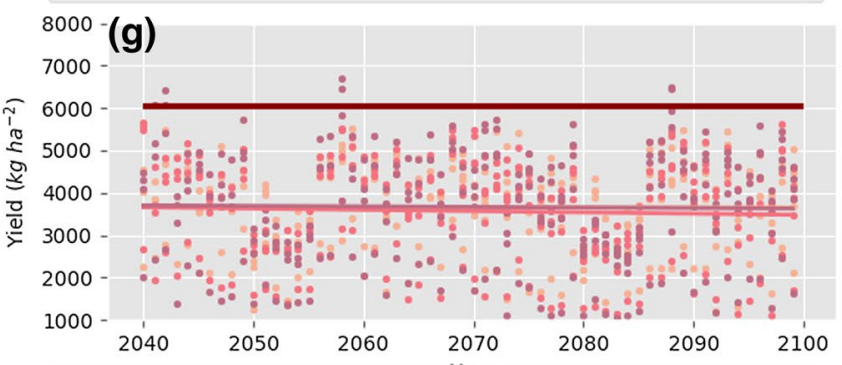

— M3 Model ns _ M4 Model ns _ M5 Model ns 。 M3 _ M4 o M5 - Base Avg.

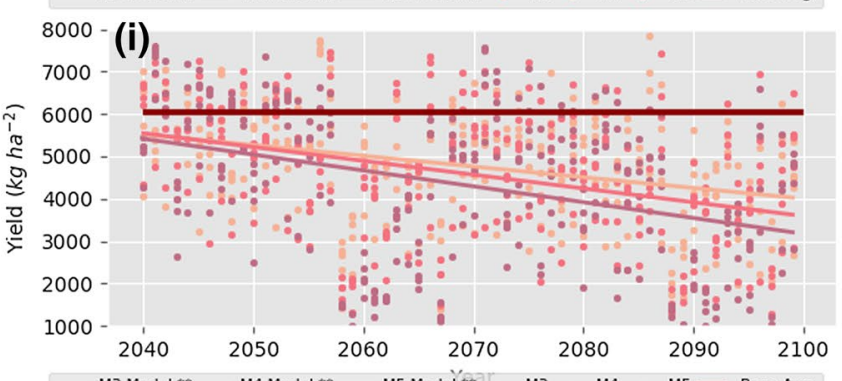

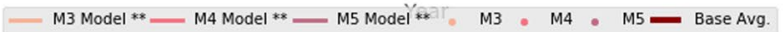

Fig. 4 Average baseline maize yields (dark red line) and projected maize yields for RCP 4.5 (left frames) and RCP 8.5 (right frames) under different sowing dates (colored points) for the following locations: $\operatorname{MTCA}(\mathbf{a}, \mathbf{b}) ; \operatorname{MTCN}(\mathbf{c}, \mathbf{d}) ; \operatorname{MTCU}(\mathbf{e}, \mathbf{f}) ; \operatorname{MTDI}(\mathbf{g}, \mathbf{h})$ and $\operatorname{MTNX}(\mathbf{i}, \mathbf{j})$ in Mato Grosso state. General average yield values for

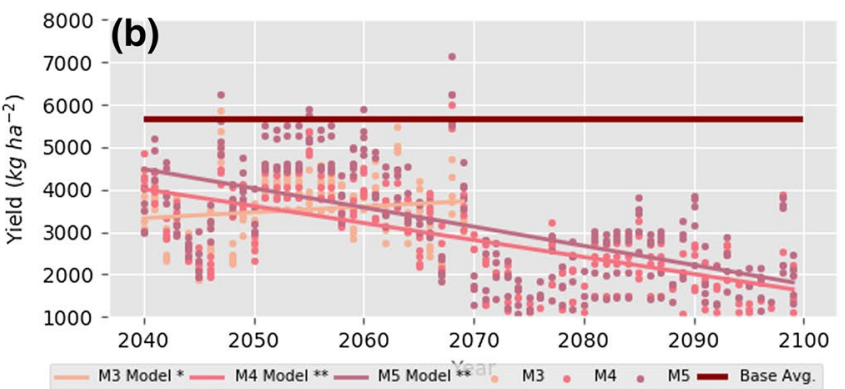

$8000-$ (d)

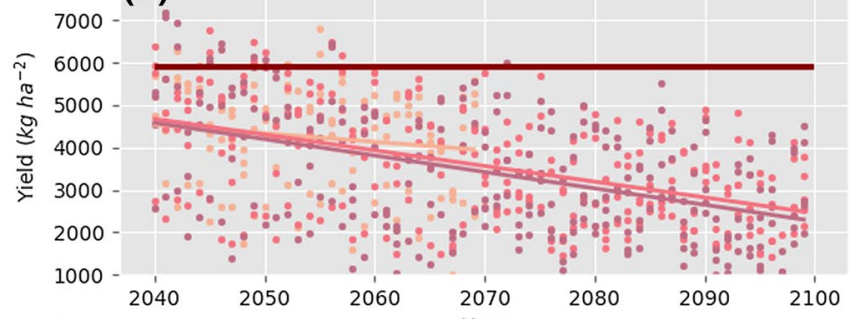

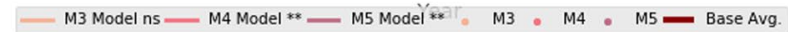

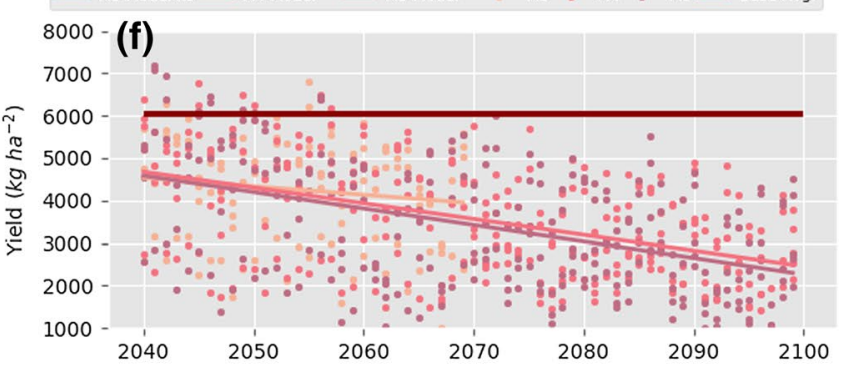

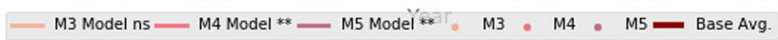
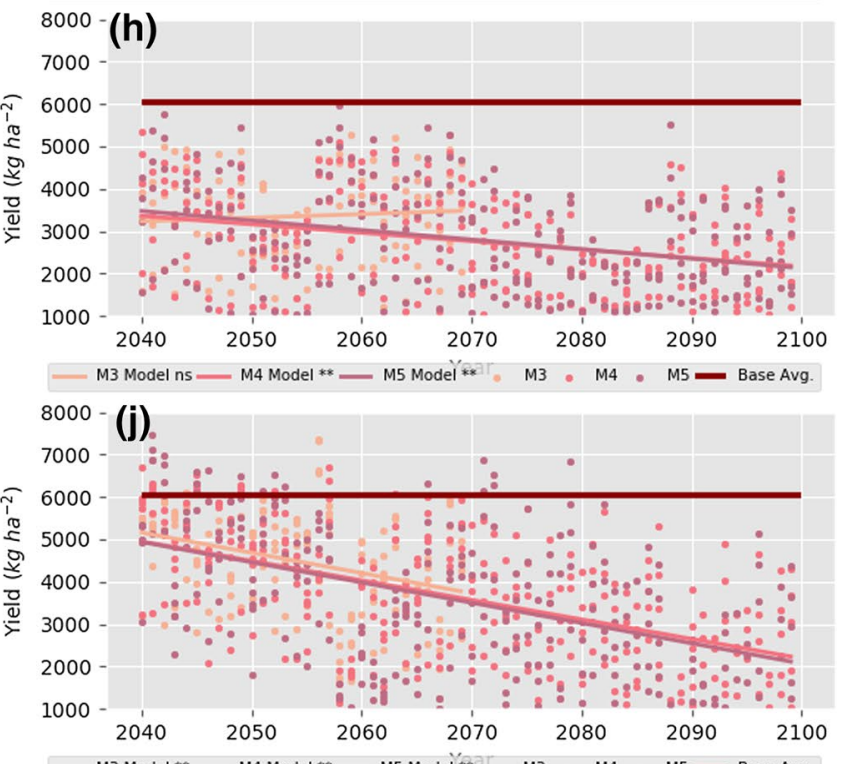

baseline scenario were 6.0, 5.8, 5.8 and $5.7 \mathrm{t} \mathrm{ha}^{-1}$ for sowing dates M2, M3, M4 and M5, respectively. Linear regression lines (colored lines) refer to yields from each sowing date within each scenario of $\mathrm{RCP}$ and region 

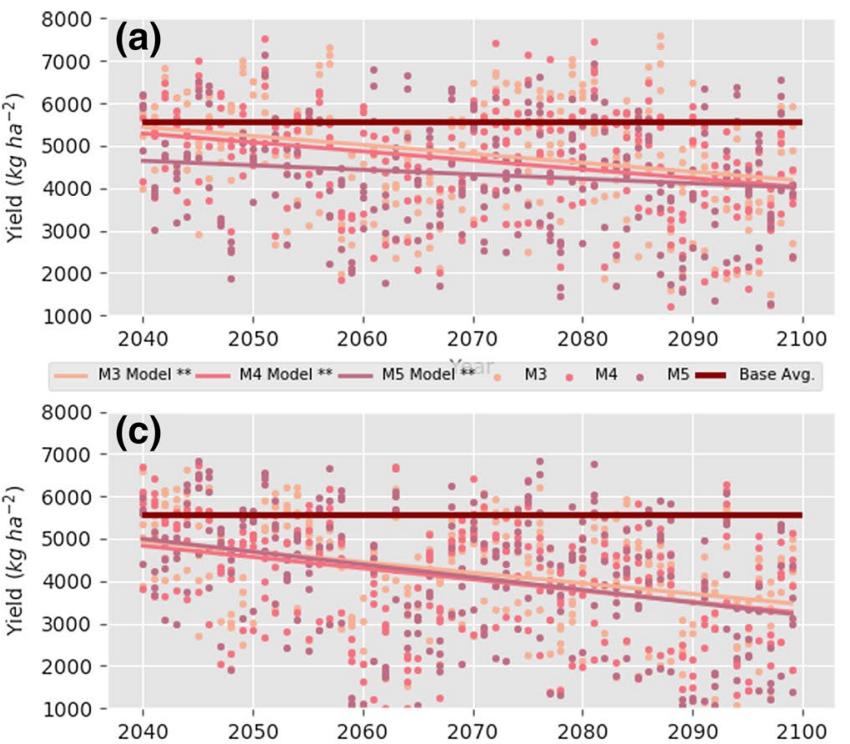

— M3 Model ** M4 Model ** M5 Model **al, M3 \& M4 . M5 - Base Avg.

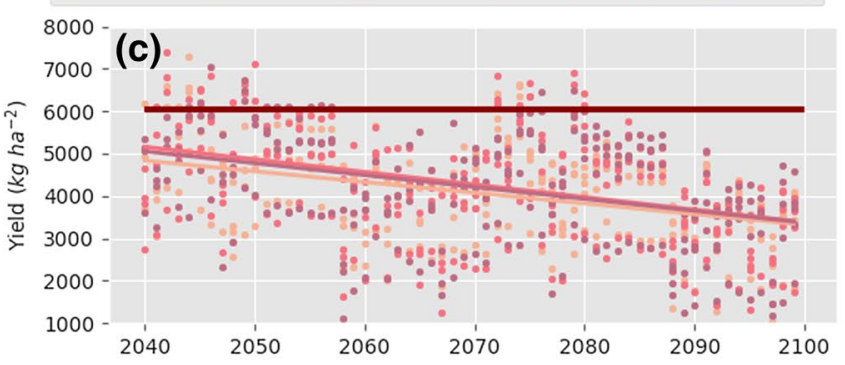

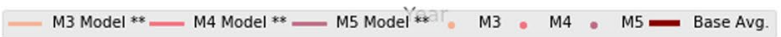

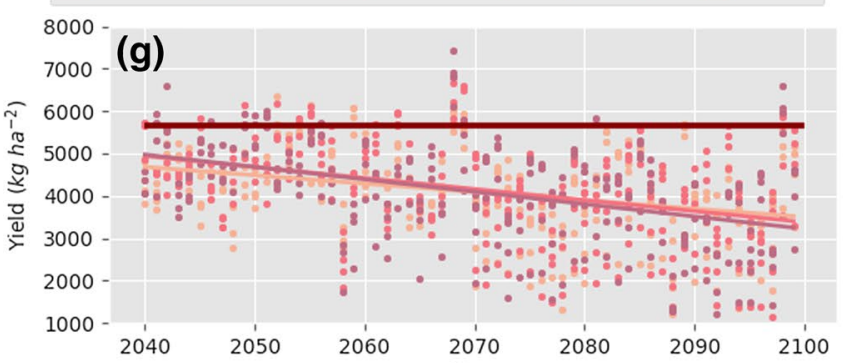

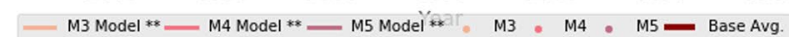

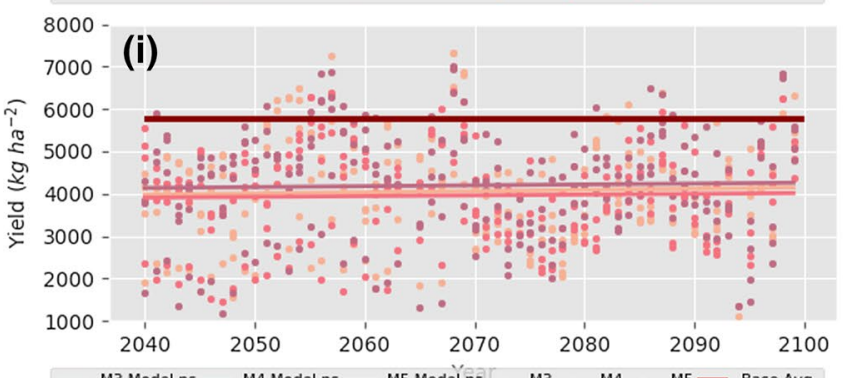

— M3 Model ns — M4 Model ns — M5 Model ns 。 M3 。 M4 . M5 — Base Avg.

Fig. 5 Average baseline maize yields (dark red line) and projected maize yields for RCP 4.5 (left frames) and RCP 8.5 (right frames) under different sowing dates (colored points) for the following locations: MTPO (a, b); MTRO (c, d); MTSI (e, f); MTSJ (g, h) and $\operatorname{MTTA}(\mathbf{i}, \mathbf{j})$ in Mato Grosso state. General average yield values for

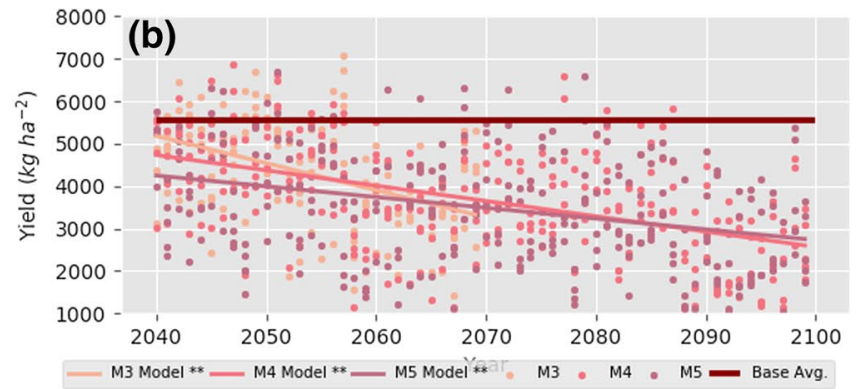

$8000-(d)$

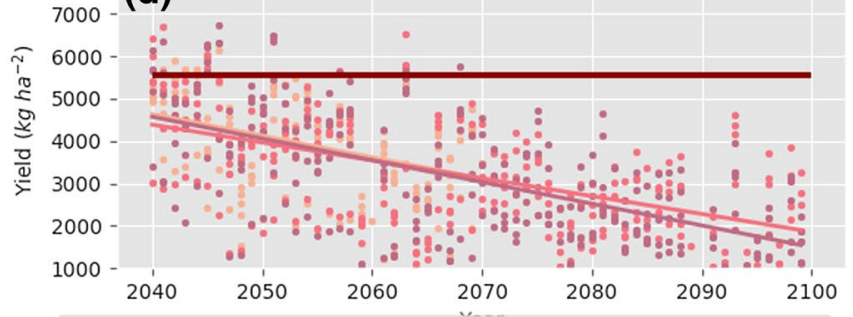

— M3 Model ** _ M4 Model ** _ M5 Model **aI, M3 \& M4 . M5 - Base Avg.

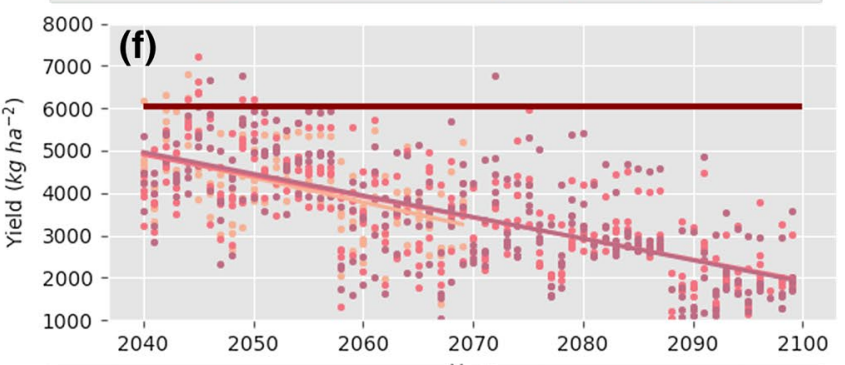

— M3 Model ** _ M4 Model ** — M5 Model ** I. M3 。 M4 。 M5 — Base Avg.

8000

7000 - (h)

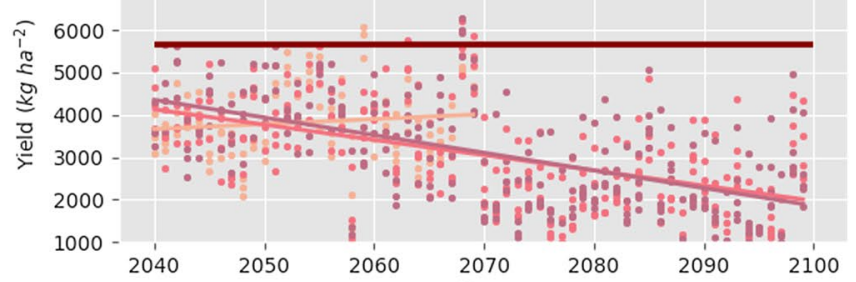

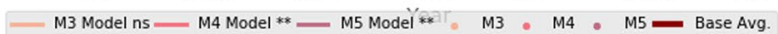

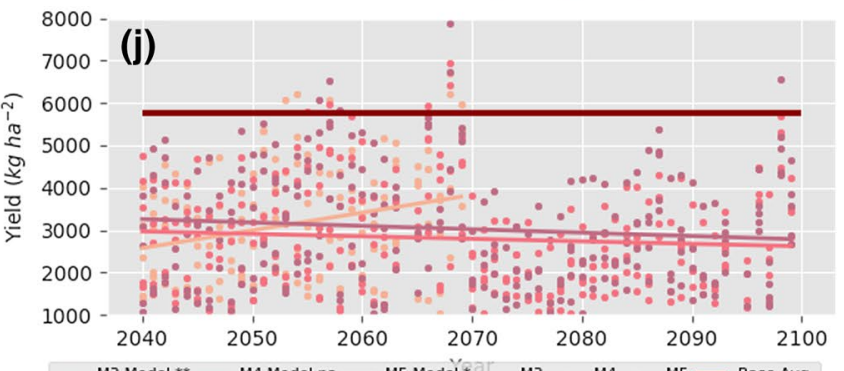

— M3 Model ** M4 Model ns — M5 Model *ar。 M3 . M4 . M5 - Base Avg.

baseline scenario were 6.0, 5.8, 5.8 and $5.7 \mathrm{t} \mathrm{ha}^{-1}$ for sowing dates M2, M3, M4 and M5, respectively. Linear regression lines (colored lines) refer to yields from each sowing date within each scenario of $\mathrm{RCP}$ and region 


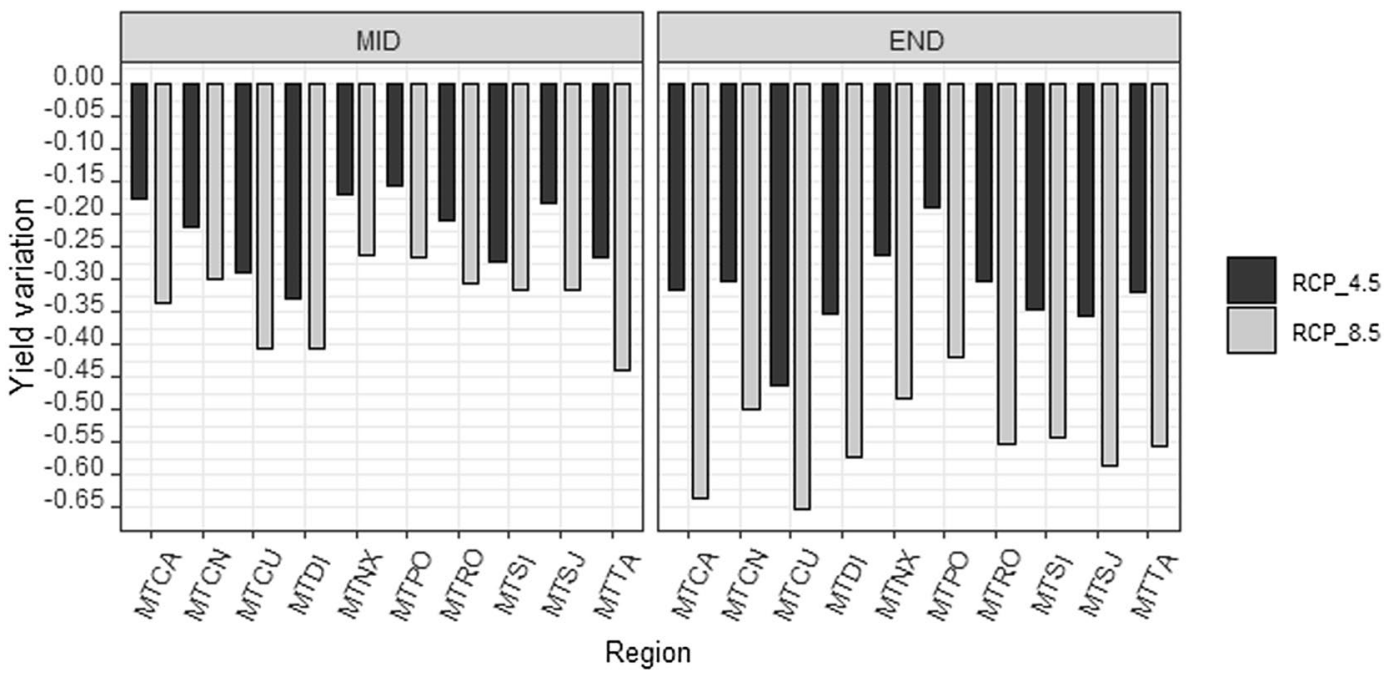

Fig. 6 Average relative variation in estimated maize yields from future climate when compared to baseline conditions for regions in Mato Grosso state

\subsubsection{Maize regional yields in projected scenarios}

In Fig. 6, it is possible to identify the relative regional projected maize yields decreases (from baseline). Average yields in baseline scenario were 5.6; 5.9; 6.0; 5.5; 6.0; 5.6; $5.8 ; 6.0 ; 5.8$; and $5.9 \mathrm{t} \mathrm{ha}^{-1}$ for the assessed regions (same order as presented in Figs. 4 and 5), and the variability between regional baseline yields was not large $\left(\sim 0.5 \mathrm{tha}^{-1}\right.$ or $<10 \%)$. However, at the projected scenarios, variability of yields between regions was higher: $-23 \% ;-32 \%$ and $-34 \% ;-55 \%$ for RCP 4.5 (mid; end) and RCP 8.5 (mid; end), respectively.

In the middle of the century, the overall average of relative yield decreases from baseline was about 15\% (despite the RCP scenario), while in the end of the century, this average reached about 35\%, evidencing the more negative effects of more accentuated climatic changes, as RCP 8.5. The largest yield decreases from baseline were found at the RCP 8.5 for all assessed regions.

When comparing the relative differences from RCP 4.5 to RCP 8.5, in the middle of the century, it was possible to observe yield decreases varying from 6 to $19.5 \%$ across regions. By the end of the century, differences grew larger and the decreases varied from 28 to $47 \%$ across regions, evidencing the most pronounced effects of RCP 8.5 when compared to RCP 4.5, especially in the end of the century. In the least favorable scenario (RCP 8.5 in the end of the century), most of assessed regions (seven) even presented yield decreases of more than 50\%, as observed for MTCA, MTCU, MTDI, MTRO, MTSI, MTSJ and MTTA. These results are an indication of the accentuated changes promoted by climate change projections also on regional climate variability.

\section{Discussion}

\subsection{Baseline climate and projections}

Climate dynamics as presented in baseline scenario, of up to 5 months of rainy season, has allowed the existence of a double-cropping agricultural system of soybean-maize in Mato Grosso in recent years [1]. However, complex interactions between geographic location, deforestation and atmospheric phenomena have contributed to the change in rainfall dynamics in both the Amazon border [28] and the entire state, causing not only a delay in the beginning, but also an earlier end of the rainy season [6]. Variation in this particular pattern of annual climate concerning rainfall (Fig. 3) and temperatures (Fig. 2) will affect and may even compromise the adequate development of at least one of the two crops in the double-cropping system $[1,17]$. Variations in climate dynamics added to crop management decisions, such as late soybean's sowing dates, will also delay maize's beginning of the cycle (Table 1) and compromise its development under lower amount of rainfall and higher temperatures.

\subsubsection{Crops}

Regarding soybean, although the impacts of temperature increase can be generally negative (in tropical regions, mostly), especially considering longer events of higher temperatures at the reproductive phase [33]; some positive effects of $\mathrm{CO}_{2}$ elevation (known as $\mathrm{CO}_{2}$ "fertilization") have been present in the past years, and they will continue to act together in the changing climate (see Online Resource 5) [41]. However, as observed in Fig. 3, 
the possible changes in the start of the rainy season, on which the high-yielding soybean development is dependent, also have to be considered. Changes in the transitional rainfall seasons and their negative impacts on soybean have already been pointed in a context of climate change of Central Brazil and regions close to Amazon [1, 6, 28, 35]. The overall yield increases (20-35\%) and longer cycles are comparable with other studies on Brazil's similar regions [32].

For maize, estimated impacts of future climate were more generally negative (Figs. 4,5 ) than for soybean. While an ensemble of crop models is widely known to provide more reliable (i.e., less variable) results [7] when a certain number of models is locally used [9], for this particular crop most studied models do agree in a strong decrease in yields due especially to temperature increases. Although an accentuated increase of $\left[\mathrm{CO}_{2}\right]$ (such as doubling current concentrations) may even have some slight positive effect on yields (maize is a C4 plant) [9], the increase in temperatures is in fact the major constraint in negatively impacting yields. The latter author reports an average of $-0.5 \mathrm{t} \mathrm{ha}^{-1}$ of maize yields decrease per ${ }^{\circ} \mathrm{C}$ of temperature increase, as also indicating that for this crop, temperature is in fact the most important climatic factor affecting yields in this century. The magnitude of off-season maize yield decreases found in this study is comparable with other studies that assessed Mato Grosso state or Midwestern Brazil [9, 31], considering the different methodological approaches.

\subsubsection{Double-cropping analysis}

At the RCP 4.5 forcing scenario, both in the middle and end of the century, even with the delayed end of soybean cycle, all current recommended maize sowing dates for projected scenarios (M3, M4 and M5) were still possible (Table 1). However, at the RCP 8.5 scenario, this was only possible when soybean was sown at an earlier date; if soybean was sown at intermediate or late dates, by the end of the century this would result in a very late beginning of maize cycle, which may not even be feasible.

It has already been pointed by studies that if the farmer wants to implement a double-cropping soybean-maize system, in most part of Central Brazil, the choice should be to start with an early soybean sowing (end of September-beginning October) to be able to cultivate maize, in the context of the whole system's profit [31]. Currently, the climatic risk of an early soybean (not enough rainfall yet) sowing is still mostly offset by the possibility of harvesting two subsequent crops [32]. However, projections found in this study (as also found by [32]) showed that the start of soybean cycle may be compromised by the delay of the rainy season due to rainfall changing patterns, as also soybean cycle gets slightly longer due to atmospheric conditions. For maize, results are even more pessimistic in the sense of the inevitable yield decreases due to warmer and more variable rainfall conditions, as found by $[26,37]$ for several regions in Brazil, which also include Mato Grosso. This is a potential threat to the recent implementation of double-cropping systems (soybean-maize), made possible by adapted genetic materials and favorable climate in Central Brazil [1]. The negative effects of RCP 8.5 were also evident on each of the assessed regions (Fig. 6). The relative decrease in tendency in all projected scenarios also became evident and quantified by the regression equation coefficients regarding the effect of time on yields in each region, also evidencing the generalized and most accentuated negative effects at the RCP 8.5 (see Online Resource 4).

\section{Conclusions}

The present study assessed the impacts of climate change projections on the dynamics of sowing dates and yields of soybean-maize in double-cropping systems in several regions of Mato Grosso, Brazil. In a general overview, temperatures are expected to only present increases, while rainfall is expected to present variable changes of both increases and decreases, depending on the time of the year.

While soybean itself did not suffer negative effects on yields, even presenting yield increases (with cycle length enlargement), it was maize that experienced the most negative effects, having a smaller recommended sowing window in a more extreme climate, significantly impacting on yields in a negative manner.

Currently, sowing dates do play a role on off-season maize yields, especially when considering increasing water constraints as sowing dates delay. But in the future, this role will be even more limiting, suggesting that even changing sowing dates may not be a feasible solution for growing maize in the double-cropping systems in Mato Grosso.

Acknowledgements The first author would like to thank CAPES (Coordenação de Aperfeiçoamento de Pessoal de Nível Superior) for the postdoctoral scholarship (PNPD/CAPES).

\section{Compliance with ethical standards}

Conflict of interest The authors declare that they have no conflict of interest.

\section{References}

1. Abrahão GM, Costa MH (2018) Evolution of rain and photoperiod limitations on the soybean growing season in Brazil: the rise (and possible fall) of double-cropping systems. Agric For Meteorol 256-257:32-45. https://doi.org/10.1016/j.agrfo rmet.2018.02.031 
2. Ainsworth EA, Long SP (2005) What have we learned from 15 years of free-air $\mathrm{CO}_{2}$ enrichment (FACE)? A meta-analytic review of the responses of photosynthesis, canopy properties and plant production to rising $\mathrm{CO}_{2}$. New Phytol 165:351-371. https://doi. org/10.1111/j.1469-8137.2004.01224.x

3. Alvares CA, Stape JL, Sentelhas PC, De Moraes Gonçalves JL, Sparovek G (2013) Köppen's climate classification map for Brazil. Meteorol Z 22:711-728. https://doi. org/10.1127/0941-2948/2013/0507

4. ANA (2017) Agência Nacional de Águas. HIDROWEB-Acervo de Dados Hidrológicos. https://www.snirh.gov.br/hidroweb/publi co/apresentacao.jsf. Accessed 10 Oct 2017

5. Andrea MCDS, Boote KJ, Sentelhas PC, Romanelli TL (2018) Variability and limitations of maize production in Brazil: potential yield, water-limited yield and yield gaps. Agric Syst 165:264-273. https://doi.org/10.1016/j.agsy.2018.07.004

6. Arvor D, Funatsu BM, Michot V, Dubreuil V (2017) Monitoring rainfall patterns in the southern amazon with PERSIANN-CDR data: long-term characteristics and trends. Remote Sens. https ://doi.org/10.3390/rs9090889

7. Asseng S, Ewert F, Rosenzweig C et al (2013) Uncertainty in simulating wheat yields under climate change. Nat Clim Change 3:627-632. https://doi.org/10.1038/ncliamte1916

8. Barbieri JD (2017) Fenômenos enos e produção de soja e milho safrinha no estado de mato grosso. Dissertation, Universidade do Estado de Mato Grosso

9. Bassu S, Brisson N, Durand JL et al (2014) How do various maize crop models vary in their responses to climate change factors? Glob Change Biol 20:2301-2320. https://doi.org/10.1111/ gcb. 12520

10. Bathiany S, Dakos V, Scheffer M, Lenton TM (2018) Climate models predict increasing temperature variability in poor countries. Sci Adv 4:1-10. https://doi.org/10.1126/sciadv.aar5809

11. Battisti R, Sentelhas PC, Boote K (2017) Inter-comparison of performance of soybean crop simulation models and their ensemble in southern Brazil. Field Crop Res 200:28-37. https:// doi.org/10.1016/j.fcr.2016.10.004

12. Bhattarai MD, Secchi S, Schoof J (2017) Projecting corn and soybean yields under climate change in a Corn Belt watershed. Agric Syst 152:90-99. https://doi.org/10.1016/j.agsy.2016.12.013

13. BRASIL (2017) Ministério da Agricultura, Pecuária e Abastecimento. Zoneamento Agrícola de Risco Climático-ZARC. https ://www.agricultura.gov.br/assuntos/riscos-seguro/risco-agrop ecuario/zoneamento-agricola. Accessed 20 Feb 2018

14. Challinor AJ, Watson J, Lobell DB, Howden SM, Smith DR, Chhetri N (2014) A meta-analysis of crop yield under climate change and adaptation. Nat Clim Change 4:287-291. https:// doi.org/10.1038/nclimate2153

15. Cohn AS, Vanwey LK, Spera SA, Mustard JF (2016) Cropping frequency and area response to climate variability can exceed yield response. Nat Clim Change 6:601-604. https://doi.org/10.1038/ nclimate2934

16. CONAB (2018) Companhia Nacional de Abastecimento-Série Histórica das Safras. https://www.conab.gov.br/info-agro/safra s/serie-historica-das-safras?start=20. Accessed 05 June 2018

17. Costa MH, Fleck LC, Cohn AS, Abrahão GM, Brando PM, Coe MT, Fu R, Lawrence D, Pires GF, Pousa R, Soares-Filho BS (2019) Climate risks to Amazon agriculture suggest a rationale to conserve local ecosystems. Front Ecol Environ. https://doi. org/10.1002/fee. 2124

18. Garcia RA, Ceccon G, Sutier GADS, Santos ALFD (2018) Soybeancorn succession according to seeding date. Pesqui Agropecu Bras 53:22-29. https://doi.org/10.1590/S0100-204X201800 0100003

19. Hatfield JL, Boote K, Kimball BA, Ziska LH, Izaurralde RC (2011) Climate impacts on agriculture: implications for crop production. Agron J 103(2):351-370. https://doi.org/10.2134/ agronj2010.0303

20. Heinemann AB, Ramirez-Villegas J, Stone LF, Didonet AD (2017) Climate change determined drought stress profiles in rainfed common bean production systems in Brazil. Agric For Meteorol 246:64-77. https://doi.org/10.1016/j.agrformet.2017.06.005

21. Hoogenboom G, Porter CH, Shelia V et al (2017) Decision support system for agrotechnology transfer (DSSAT) version 4.7 Gainesville. DSSAT Foundation

22. Instituto Brasileiro de Geografia e Estatística (IBGE) (2017) Sistema IBGE de Recuperação Automática-SIDRA-Produção Agrícola Municipal. https://sidra.ibge.gov.br/pesquisa/pam/ tabelas. Accessed 10 Aug 2018

23. Instituto Nacional de Meteorologia (INMET) (2018) BDMEPBanco de Dados Meteorológicos para Ensino e Pesquisa. https ://www.inmet.gov.br/portal/index.php?r=bdmep/bdmep. Accessed 01 Nov 2017

24. International Panel on Climate Change (IPCC) (2014) AR5 synthesis report: climate change 2014. https://www.ipcc.ch/repor t/ar5/syr/. Accessed 10 Sept 2018

25. Jones JW, Hoogenboom G, Porter CH et al (2003) The DSSAT cropping system model. Eur J Agron 18:235-265. https://doi. org/10.1016/S1161-0301(02)00107-7

26. Justino F, Oliveira EC, Rodrigues RDÁ et al (2013) Mean and interannual variability of maize and soybean in Brazil under global warming conditions. Am J Clim Change 02:237-253. https://doi. org/10.4236/ajcc.2013.24024

27. Kasecker TP, Ramos-Neto MB, da Silva JMC, Scarano FR (2018) Ecosystem-based adaptation to climate change: defining hotspot municipalities for policy design and implementation in Brazil. Mitig Adapt Strateg Glob Change 23:981-993. https:// doi.org/10.1007/s11027-017-9768-6

28. Leite-Filho AT, Costa MH, Fu R (2019) The southern Amazon rainy season: the role of deforestation and its interactions with large-scale mechanisms. Int J Climatol. https://doi.org/10.1002/ joc.6335

29. Long SP, Ainsworth EA, Leakey ADB, Nosberger J, Ort DR (2006) Food for thought: lower-than-expected crop yield stimulation with rising $\mathrm{CO}_{2}$ concentrations. Science 312:1918-1921. https ://doi.org/10.1126/science.1114722

30. Minuzzi RB, Lopes FZ (2015) Desempenho agronômico do milho em diferentes cenários climáticos no Centro-Oeste do Brasil. Rev Bras de Eng Agríc e Ambient 19:734-740. https:// doi.org/10.1590/1807-1929/agriambi.v19n8p734-740

31. JúniorSentelhas RDSNPC (2019) Soybean-maize succession in Brazil: impacts of sowing dates on climate variability, yields and economic profitability. Eur J Agron 103:140-151. https:// doi.org/10.1016/j.eja.2018.12.008

32. Pires GF, Abrahão GM, Brumatti LM, Oliveira LJC, Costa MH, Liddicoat S, Kato E, Ladle RJ (2016) Increased climate risk in Brazilian double cropping agriculture systems: implications for land use in Northern Brazil. Agric For Meteorol 228-229:286-298. https://doi.org/10.1016/j.agrformet.2016.07.005

33. Puteh AB, Thuzar M, Mondal MMA, Abdullah NAPB, Halim MRA (2013) Soybean [Glycine max (L.) Merrill] seed yield response to high temperature stress during reproductive growth stages. Aust J Crop Sci 7:1472-1479

34. QGIS Development Team (2018) QGIS geographic information system. Open source geospatial foundation. https://qgis.org

35. R Core Team (2018) R: a language and environment for statistical computing. Foundation for Statistical Computing, Vienna

36. Ray DK, Gerber JS, MacDonald GK, West PC (2015) Climate variation explains a third of global crop yield variability. Nat Commun 6:1-9. https://doi.org/10.1038/ncomms6989

37. Resende NC, Miranda JH, Cooke R, Chu ML, Chou SC (2019) Impacts of regional climate change on the runoff and root 
water uptake in corn crops in Parana Brazil. Agric Water Manag 221:556-565. https://doi.org/10.1016/j.agwat.2019.05.018

38. Rosa HHR (2019) Irrigação na coinoculação de microoganismos na cultura da soja e milho. Dissertation, Universidade do Estado de Mato Grosso

39. Rosenzweig C, Jones JW, Hatfield J et al (2013) The agricultural model intercomparison and improvement project (AgMIP): protocols and pilot studies. Agric For Meteorol 170:66-182. https:// doi.org/10.1016/j.agrformet.2012.09.011

40. Ruane AC, McDermid SP (2017) Selection of a representative subset of global climate models that captures the profile of regional changes for integrated climate impacts assessment. Earth Perspect 4:1-20. https://doi.org/10.1186/s4032 2-017-0036-4

41. Sakurai G, lizumi T, Nishimori M, Yokozawa M (2014) How much has the increase in atmospheric $\mathrm{CO}_{2}$ directly affected past soybean production? Sci Rep 4:1-5. https://doi.org/10.1038/srep0 4978

42. Soler CMT, Sentelhas PC, Hoogenboom G (2007) Application of the CSM-CERES-Maize model for planting date evaluation and yield forecasting for maize grown off-season in a subtropical environment. Eur J Agron 27:165-177. https://doi.org/10.1016/j. eja.2007-03-002

43. Urban DW, Sheffield J, Lobell DB (2015) The impacts of future climate and carbon dioxide changes on the average and variability of US maize yields under two emission scenarios. Environ Res Lett. https://doi.org/10.1088/1748-9326/10/4/045003

44. Wickham H 2017 Tidyverse: easily install and load the 'Tidyverse' packages. R package version 1.2.1. https://www.tidyverse.org/. Accessed 01 Mar 2018

45. Xavier AC, King CW, Scanlon BR (2016) Daily gridded meteorological variables in Brazil (1980-2013). Int J Climatol 36:26442659. https://doi.org/10.1002/joc.4518

46. Zhao C, Liu B, Piao S et al (2017) Temperature increase reduces global yields of major crops in four independent estimates. PNAS 114:9326-9331

Publisher's Note Springer Nature remains neutral with regard to jurisdictional claims in published maps and institutional affiliations. 